\title{
Transatlantica
}

Revue d'études américaines. American Studies Journal

\section{Academic Journals and Publications : Mapping the} Territories.

A Debate on the Publication of American Studies Journals

Divina Frau-Meigs, Catherine Bernard, Noëlle Batt, Jean Kempf, Georges-Claude Guilbert et Michel Bandry

\section{(2) OpenEdition}

Journals

Édition électronique

URL : http://journals.openedition.org/transatlantica/555

DOI : $10.4000 /$ transatlantica.555

ISSN : 1765-2766

Éditeur

AFEA

Référence électronique

Divina Frau-Meigs, Catherine Bernard, Noëlle Batt, Jean Kempf, Georges-Claude Guilbert et Michel Bandry, «Academic Journals and Publications: Mapping the Territories. », Transatlantica [En ligne], 1 । 2003, mis en ligne le 24 mars 2006, consulté le 29 avril 2021. URL : http://journals.openedition.org/ transatlantica/555; DOI : https://doi.org/10.4000/transatlantica.555

Ce document a été généré automatiquement le 29 avril 2021.

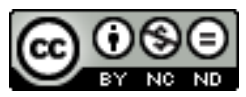

Transatlantica - Revue d'études américaines est mis à disposition selon les termes de la licence Creative Commons Attribution - Pas d'Utilisation Commerciale - Pas de Modification 4.0 International 


\title{
Academic Journals and Publications : Mapping the Territories.
}

\author{
A Debate on the Publication of American Studies Journals \\ Divina Frau-Meigs, Catherine Bernard, Noëlle Batt, Jean Kempf, \\ Georges-Claude Guilbert et Michel Bandry
}

\section{NOTE DE L'ÉDITEUR}

[Please inform the editor if you find a mistake, a forgotten link or if you wish to add information or react to the papers]

Introduction by Divina Frau-Meigs

1 (About the author : Professor, University of Orléans, co-editor of Revue Française d'Etudes Américaines and TransatlanticA, member of the editorial board of Sources (University of Orléans) and MédiaMorphoses (Institut National de l'Audiovisuel))

Debating about academic publications as territories makes sense because journals reflect our imaginary, somewhat utopian, vision of scientific collaboration and exchange, with its attendant values of knowledge sharing, of multiple viewpoints, of freedom of self-expression and freedom from selfish interests. Journals however behave like real territories: they cut up boundaries, within disciplines and within universities; they set anchor either in local waters or in national and international harbors. More concretely, they also place individual researchers on the map as they provide legitimacy, recognition, quotation, and eventually pave the way for a successful carrier and inclusion in the larger community of scholars.

Territories are also about identity and visibility, a fact that became sorely apparent to our community of American studies researchers during the various recent crises that the United States has dealt with : the controversial presidential election of 2000, the Twin Towers attacks of September 11th 2001, the anti-terrorist wars of Afghanistan and 
Iraq. The need for thoughtful scientific analysis was seriously tested by the urgency to keep up with current events. RFEA and TransatlanticA contributed issues on the topic (see RFEA, issue 89 on the elections, TransatlanticA, installment 1 on 09/11), but it was not an easy task. The role of our community as providers of complex explanations and long-term understanding appeared as essential to offer balanced views of the United States, especially in a time when our own country, France, was itself under attack and under stress. This role is not going to diminish as our societies become increasingly global and as world governance is, arguably, led by the United States.

4 As a result, the debate within our community has been relaunched about our capacity to react fast and to make a difference with the media. The realit-that journals are not about journalism-has brought us to the realization that we must keep working at a double task : we must maintain a cool and cooling distance to events and yet we need to provide some " gray matter", some unfinished yet compelling piece of thought, to feed to the media in times of rapid change, so that our informed point of view penetrates the public space and so that our community remains engaged in the national and international debates. This may imply two different types of publications and different time frames: the finished article-necessarily slow-, the work-in-progress papernecessarily unpolished.

5 This dual strategy may be facilitated by on-line options, like e-prints or pre-prints databases, allowing us to make our working papers available to a wider community without waiting for the time-consuming process of reviewing and rewriting (Chartron 200 ; Guédon 2002). We have tried to offer our community this dual path, with the development of an on-line journal, TransatlanticA, together with the maintenance of RFEA. This repositioning is not without trouble and our colleagues seem to find it difficult to depart from traditional formats. The road for challenging territories to explore still remains open in that respect and the "open archives" movement, supported by the Budapest Open Access Initiative (BOAI), launched in February 2002, needs to be watched closely by our scholarly community. Our own national and European views about access, common good, public domain, and knowledge sharing and building in a public service perspective are seriously coming under attack (Quéau 2002). If we do not engage ourselves more actively in thinking-through our editing and publishing patterns we may be left behind in the so-called « information society ». And yet, as a specific community which has developed an intellectual and linguistic agility in dealing with the Anglo-american culture, our role of « passeurs » can be crucial.

6 Within our community, however, identity is less about outside visibility and policy than about legitimacy and self-promotion, to which journals contribute via their articles selection and production. The concrete unit of analysis then is the article, as a separate item, with a life quasi of its own. A published article contributes to the identification of its author and its recognition among its peers. It seals one's belonging to a team, to a research laboratory and marks the institutional territories that we are all vying to invest and investigate. It also signals a whole process of consensus-building and of co-option whereby some are included and others are left out or on the margins (Quinton 2002).

7 The legitimacy of our journals runs counter issues of argumentation and certification, two processes that are different but feed on each other in practice. The journal editors strive at maintaining the argumentative value of the articles they select either by peer-reviewing or of their own authority. This charge in itself is quite a social 
responsibility and they tend to ignore any other, especially as to what happens to the life of the articles published. They think at best of the notoriety they will derive from their task, which is collective (the journal) and not itemized (each article in the collection the journal gradually builds-up). Certification on the other hand is what happens to the life of the article and its author after publication, postpartum. Done by members of the same class, that are both judge and party, it gives currency to the article, and like paper money, gives credit (or discredit) to the author. The article then becomes a kind of "unit of account for one's career " (unités de compte des carrières, Quinton, 189), itemized in the list that appears at the appropriate slot in one's curriculum vitae. Intellectual property value and institutional administrative logics cohabit, with the dangerous drift seen among some colleagues, who write articles to make them fit in with conference topics and will neglect their own research interests and their own construction of the field. The responsibility of scientific and professional associations is thus engaged when they encourage thematic conferences exclusively, to the detriment of more open workshop procedures.

In France this double-bind is reinforced by the institution of Conseil National des Universités (our National Board of Evaluation). Its role is to certify colleagues who wish to become associate professors or full professors and to promote them within the salary system. This is often done on the basis of the quantity of publications produced, rather than on their quality (this task being left to the editors and publishers and their boards). Arguably, the presence of this qualifying instance also may accelerate a process already existing in the hard sciences, the tendency to favor the production of articles over the productions of books, on the grounds that the latter are too long and become obsolete too soon. Postmodern criticism has long predicted the dominance of articles over books and of the digital culture over the paper tradition. The current situation however shows a bi-polar situation : paper endures and remains,--perennial - , on-line booms and busts,-all pervasive. This seems to point to a division of labor between the media and their diffusion: paper keeps the weight of legitimacy while digital allows for more visibility. Both remain pertinent in terms of publication alternatives. None are free, in spite of the supposed cost-effectiveness of the electronic format.

9 A quick look at our French territory reveals the weakness of our situation in the light of this recent evolution. The report on the state of American Studies (see annex 3 " éditeurs et revues ", Kempf 2002) reveals that there are 11 journals devoted to English studies, at national level, only one of which focuses on American studies (RFEA). The on-line publications situation is worse, with fewer titles, and only TransatlanticA for American studies. The local landscape is richer, with about 30 titles, but it offers a very mixed batch (of bulletins, annals, etc.). The dependency as to the associations or the universities that host such journals is great, and to be contrasted to the autonomy of American publications, often professionally managed, with their own secretariat and their own line of funding.

10 So when dealing with journals, we have to keep in mind these competing criteria (legitimation, certification and even qualification), and these competing formats and means of distribution (paper and digital). They do not help us clarify the different paths to success; they are evidence and traces that we are in a time of transition, when crucial decisions have to be made, crossroads negotiated and roads not taken. 
11 Convening a roundtable on these issues is both tantalizing and frustrating because not all points of this complex process can be tackled in one session. So the roundtable reflects the sharing of a variety of experiences, in pragmatic fashion. It covers international, national and local grounds, it questions on-paper and on-line strategies, it examines criteria for legitimation, certification and qualification. Hence the presence of a variety of actors in the process, without any claim for exhaustive representation. Catherine Bernard

12 (About the author: Professor, University Paris 7-Denis Diderot, editor of Les Cahiers Charles $V$, journal of the Faculty of English and American Studies, University Paris 7 ; joint editor of The European Journal of English Studies, official journal of the European Society for the Study of English, with Claire Connolly (Cardiff University) and Ansgar Nünning (University of Giessen))

13 As the editor of two journals, one in France and the other in relation with a European academic structure, I have had ample occasion to compare the editorial practices of French academia and those of our colleagues throughout Europe. I have also had the opportunity to compare the respective merits and drawbacks of two very different modes of editing and publishing, whether the journal is financed by a private publisher or funded by a university.

Les Cahiers Charles V were created in 1979 and have been successively edited by Michel Gresset and Claire Bruyère. They are financed by the sales of each issue, subscriptions (essentially coming from University libraries) and a grant from the research budget of Paris 7. Its purpose is to reflect the research that is being done in the Faculty of English and American studies of Paris 7 and its links with other research centers in France and abroad. It has a working reading committee and an international advisory board. It only publishes thematic issues meant to provide a state of the arts vision of a given theme of research. Each issue is edited by a guest editor who is also a member of the Faculty and who can solicit articles from within or without our institute.

15 The fact that it is inter-disciplinary is both an asset and a drawback. Each issue being geared to a very specific audience, in turn made of specialists of linguistics, literature or what in France we define as « civilization » (elsewhere also called « area studies »), it has proved over the years difficult to build up a loyal readership and to increase the number of individual subscriptions.

16 The main difficulties encountered by such a publication are those of most publications of its kind, difficulties that suggest it is probably high time we start reflecting on our own editorial practices, on the way we can give our research endeavors greater visibility and probably as well on the very kind of research we will in the future choose to invest an ever more precious time in.

17 The first difficulty derives from the absence in Paris 7 of university presses. University presses are too rare in France. Even rarer are the Presses ready to invest in the production of usually non-profit making journals whose circulation often remains unsatisfactory. The time has come maybe to consider pooling our financial and academic resources, although such team work involving several universities would of course be in contradiction with the way research is funded in France and the necessity for each research group to have its own publishing channel which ensures some kind of visibility to the research carried out, whether it be a journal or a series of volumes of articles. This should not however stop us from assessing collectively the quality of such 
so-called visibility. To put it bluntly what is the point of publishing journals whose circulation is unreliable and which fail to attract the readership they rightly deserve?

One way of solving this difficulty may undoubtedly be to develop the publication of journals on-line, a solution illustrated with Cercles and Transatlantica at this round table. One should not underestimate what a complex process on-line publishing can be for the journals' editors. One should not underestimate either the changes this would mean in our research practices :

- Should the publication go exclusively on-line without retaining a hard copy paper version? On-line publication would undoubtedly ensure greater visibility for the journal. However, it also seems to me that it would mean the end of the thematic format. Browsing will be rarer as those who choose to connect themselves will more likely than not prefer to read and possibly download only the article that is of immediate interest to them.

- By way of consequence, how are we to limit the development of what could be defined as « scholarly endogamy » which is likely to be the end of the pluridisciplinarity of our discipline?

The second difficulty one should address collectively is that of the language of publication. One can understand that France should be keen to defend its linguistic heritage. However one may also find it odd that we still feel compelled to publish essentially in French, whereas we intend to write for an international readership with whom we share a language which also maps our field of research.

The third problem we should address is even more complex and is not specific to French university publishing. I have also been confronted with it as joint editor of The European Journal of English Studies. It has something to do with the form of temporality in which we choose and possibly should inscribe our research.

Most likely, the European nature of this editorial venture has made me hyper-aware of this question which is in fact rarely raised. This journal was produced in the wake of the creation of The European Society for the Study of English in 1990. The members of the initial editorial board were Kate Belsey (Centre for Cultural and Critical Theory, Cardiff University), Herbert Grabes (Giessen University), Jean-Jacques Lecercle (University Paris X-Nanterre). The purpose of this journal was from the start both simple and complex : it was meant to foster an ongoing dialogue between the various communities of English and American studies specialists across Europe, and to promote the circulation of ideas among this vast and varied community. I will not be presumptuous enough to explain to a community of scholars of American culture how multifarious the Europe of English and American studies may be. The European Association of American Studies has been a living proof of this multiplicity for a long time. It is precisely one of the great and wonderful lessons of working at an international level to understand that we work on different time layers, each national community having reached a different moment of our joint history, because of its own history, because of the way it is structured and even financed. It is common knowledge that France is still, to some extent, lagging behind other nations in Europe in the matter of library resources, which has compelled us to develop a different form of research that relies for instance heavily still on a more formalist reading of literature.

The task of a journal such as The European Journal of English Studies was, in the minds of its founders, to create a forum where this diversity could be acknowledged rather than suppressed and to allow us to learn from other definitions or conceptions of our common object of study, the idea being to bring down the hermetic partitions between 
our respective traditions and not simply to add yet another title to the awe-inspiring list of journals of English studies in Europe (see the list compiled by Balz Engler and published in the newsletter of the association, The Messenger, $\mathrm{n}^{\circ} 3.1$; the list numbered 349 journals and only included the journals whose editors had replied to our colleague's call).

The intention was to resist both the excessive specialization previously mentioned and the imposition of a theoretical doxa emanating from Britain and the United States. Each issue is placed under the responsibility of a guest editor whose task is to solicit articles from as wide a range of European countries as possible and focuses on a theme meant to cover a question that is currently attracting particular attention in the field of literature, linguistics or cultural studies.

The difficulties of such a venture are many. A form of cultural tropism makes us naturally turn our gaze towards Britain and the United States as the sources of theoretical inspiration and it is thus quite a challenge to prove that the rest of the research done in Europe may be invested with the same credibility. It is not so much simply that "we do things differently on the continent»; it is not so much that difference as such may be suspect but that the very status of our discipline cannot be the same depending on whether we teach English literature in Birmingham or in Paris 7, in Timisoara or at King's College, London. This may be obvious. This however has momentous consequences on the viability of such a venture as a European journal of English or American studies. Furthermore, a private publisher will always favor the publication of miscellaneous issues that will attract a wider audience, whereas such a journal should not, to my mind, try to compete with other well established journals publishing miscellaneous articles.

In spite of all this, it is the task of the editors of European journals to use what may seem difficulties and contradictions to foster a collective reflection on the very logic of our discipline, on its tensions and its limitations.

Such stock-taking implies that one should have the time to reflect and ponder, which does not always easily combine with the pressures of the market whether it be that of academic publishing or of academia itself. Both my experiences as editor in France and at a European level have taught me that one should try and resist such pressure as best one can and that research should have the time to develop itself at its own pace, inscribed as it must be in the "longue durée». It benefits from efficient peer-assessment, contacts at home and abroad. The mission of university publishing should be to foster such slow and at times painstaking progress.

We have in that respect, it seems to me, a lot to learn from the way the reading committees of most English and American journals function which precisely take such slow progress into account and do not hesitate to ask authors to rethink, rewrite, reread and who submit the articles to specialists of the given topic dealt with in each article. Undoubtedly the publishing schedules are not those we are accustomed to in France. My intention is not to question the quality of the research that is being done in France or anywhere else in Europe and one must acknowledge the fact that the publishing procedures that are privileged here contribute to the diversity of modes of thinking that remain intrinsically reticent towards the influence of the current theoretical doxa. the only guarantee we have against the current tyranny of ready-to-wear thinking. The 
reflection initiated during the 2003 congress of the French Association of American Studies is a sign that we feel the time has come to reassess precisely the priorities that should be those of academic publishing so as to make our common labor both more widely known and ever more relevant.

Noëlle Batt

(About the author: Professor, University Paris 8-Saint Denis, editor of TLE "recherche en revue")

The journal TLE was created in 1981 by a few members of a research team located at the University of Paris 8-Vincennes at St-Denis and led at the time by Professors Olga Scherer and Christine Brooke-Rose. The group was involved in theoretical thinking on narratology based on a body of works from American and English literature. In 1984, the journal came under the auspices of the University Press of Paris 8 (alongside other journals like Hors-cadre, Médiévales, Histoire. Epistémologie. Langage, Extrême Orient-Extrême Occident and Recherches linguistiques). A new editorial program was established in accordance with the team's new research project on the evolution of the processes of representation in English-language fiction.

31 Issue number 6 (1988), «Literary Representation : New Conceptual Models », defined a new and challenging goal for the journal-one which has continued to be its signature ever since. TLE was to act as a forum both for developing theoretical thought on the dynamics of literary systems and for stimulating conceptual collaboration between literary theory and other disciplines such as semiotics, philosophy, linguistics or epistemology.

From Issue 8 («Literature and Cognition ») onward, a privileged relationship was established with cognitive science (issues $8,9,10,11,17$ ), complexity theory (issues 8 , $15,16,18)$, the theory of non-linear dynamic systems (issue 12) and Deleuzian philosophy (issue 19). In each case, the concern was to work on the borderline between different disciplines, in order to build bridges between concepts and to adopt and adapt those which would be most likely to serve a critical approach to literary texts in fiction and poetry alike. The main body of works studied in the journal continued to be taken from American and English literature, although new colleagues who had joined the team were studying French, German, Russian or South American literature. More than ever, the chief ambition of the journal was to contribute to the emergence of crucial questions concerning the position of literary studies in the field of the human sciences today, with a clear awareness of the need to conduct a certain amount of interdisciplinary work and to contribute to a problematization of methods and procedures.

33 The journal is published once a year, in a run of 400 copies. All editorial work is done by the editorial board, with the help of editorial advisers. The actual journal is produced by the University Press. A common distributor for French university presses (AFPU-diffusion) is responsible for its placement in bookstores. Information about the journal can be found on the Paris University Press website http:// www.puv-univ-paris8.org.

At a time when the word «interactive " has become the almost exclusive property of communication on the web, and when almost all journals are considering their future on-line, I should like to insist on the numerous interactions that a printed journal is still capable of stimulating. You can have the pleasure of taking a printed journal off a library shelf because you like the smoothness of the cover, because the name of a 
foreign scholar catches your eye, because the title of such-and-such an article just happens to coincide with your current preoccupations, because sometimes it is simply pleasurable to let yourself be guided by sheer curiosity... Choosing to allow time to take its time or surrendering to the impulse to run your fingers over a surface on which letters and words happily leap and dance-these are certainly not indifferent actions in an age in which speed and over-activity all but rule supreme. A visit to the 13th Salon des Revues (Journals Fair) which will take place on October 18-19th 2003, at the Espace des Blancs-Manteaux, in Paris, will surely do more to convince you of this than any further arguments along these lines.

I should nevertheless like to conclude with a word on a theme that I developed a few years ago in a volume devoted to the link between Research and Journals (Didier and Ropars 1994). A journal that opens its pages to the work of a research group is more than just a space in which things get published, although to some extent it is obviously this too. For it is not merely a place where writings are inscribed and preserved; it is also a call for writing. As such, it is a true partner-a hetorotopia which allows a research team to regard itself as a constant becoming of new thoughts and novel inscriptions.

Georges-Claude Guilbert

(About the author: Associate professor, University of Rouen, editor in charge of book reviews for Cercles)

The electronic journal Cercles is the result of the collaboration of four general editors : Antoine Capet, Georges-Claude Guilbert, Philippe Romanski and Aïssatou Sy-Wonyu. But it is first and foremost the product of Philippe Romanski's academic and technological expertise. It can be found on the web at http://www.cercles.com. Cercles made the move from paper to electronic publishing a few years ago; it was then decided to transfer on the web the capacities and the know-how developed on paper, without transforming the traditional editorial line of the journal.

\section{The Articles}

Every issue of Cercles is devoted to a particular theme, chosen either by one of us four, or suggested by a member of our prestigious editorial board. We occasionally welcome suggestions from colleagues who are not linked to Cercles on a regular basis and who may wish to edit an issue.

39 I myself edited issue \#3, "British and American Popular Music: Subversion and/or Entertainment?» (2001), thus opening the webpages of Cercles to the field of Cultural Studies and Gender Studies. I prolonged this with issue \#8, «Gender, Race and Class in American TV Sitcoms » (2003). Issue \#8 is entirely in English, which is the result of a deliberate policy : our readership is international; we are particularly well-known in U.S. academic circles, and most of our collaborators teach in English departments.

2.The Book Reviews

40 I am the sole book review editor of Cercles. Following the logic detailed above, we review mostly books written in English and write our book reviews in English. I have heretofore given particular attention to English and American literature, twentieth-century English and American history, Film Studies, Cultural Studies, and LGBTQ Studies, but our scope is widening.

- Dealing with publishers : Editing book reviews means getting to know the publicity managers of publishing companies and winning their trust. After slow beginnings in 2001, I 
can now say that practically every American and British publisher takes us very seriously indeed, and sends us all the books we request, as well as unsolicited review copies. We are starting to deal with German and Danish publishers too (French publishers, on the other hand, are much more difficult and grudging). I am compelled to limit the number of books we review, for material reasons : having no financing, I have no help and spend a considerable amount of my time packing and dispatching books, etc. Some publishers have taken to quoting us on their websites

- Dealing with reviewers : I experience no difficulty recruiting reviewers worldwide ; indeed I often receive spontaneous offers of collaboration. I do have quite a lot of work editing reviews, though, since not everyone is as respectful of English grammar as I would wish. My principal predicament is linked to the deadlines I try to impose, since far too many colleagues tend to disregard them. I believe Cercles book reviews should appear online within six months after the release of the books-for obvious reasons-and my Australian, British and American collaborators seem to agree with me. Unfortunately, many of my French collaborators evidently do not.

- Dealing with authors : We get a fair bit of feedback from the authors of books we review, generally rather positive. They e-mail to express their satisfaction, occasionally their misgivings. Some quote our reviews on their websites.

- Dealing with readers : The readership of the book reviews grows daily and is larger than the readership of our articles. Our readers are located all over the planet, with strong concentrations in the U.S., the U.K., and France. We often receive e-mails from professors complimenting us and letting us know that they recommend Cercles to their students and colleagues. Several have linked their own academic websites to Cercles. We try to answer every query and react to every suggestion.

41 To conclude, I see Cercles as a success that gives quite a lot of satisfaction, even though there is plenty of room for improvement, naturally. My only regret is that a number of colleagues-again, especially in France-continue to distrust electronic publications, displaying, dare I say, a somewhat fetishistic attachment to paper. It is true that " anything goes » on the Internet, but that does not mean people cannot recognize quality or at least academic seriousness when they see it. It is true too that we cannot certify that everyone of our readers has at least a BA, as has been (not jocularly) pointed out to me; but I myself do not see that as a problem. This is the twenty-first century, I am convinced the future of academic journals lies in electronic publication. And judging by the influx of new e-journals of the same type as Cercles, many share my conviction. Paper and cyberspace may coexist harmoniously, not to the detriment of culture, on the contrary.

Jean Kempf

(About the author : Professor, University Lyon 2-Lumière, editor of TransatlanticA, the on-line journal of the Association Française d'Etudes Américaines)

As far as e-journals are concerned we can only be sure of one thing : they do not exist yet-even though some of us edit them and write for them. With e-publication, academics are faced with the first real revolution in the production of their work since... the invention of the Xerox machine ! Or most probably since the emergence of the modern social sciences in the late XIXth century. For more than a century, academic publishing had merely been "more of the same». Today, electronic technologies may give us opportunities to reinvent the way we structure our professions, our exchanges, that is to say the way we produce knowledge. This is not a 
totally uninteresting perspective. Hence the few remarks I would like to contribute, from the vantage point of my practice as editor of TransatlanticA and my work at University Lyon 2 on a rejuvenated and innovative comprehensive scheme of scholarly publishing integrating all media, from the web to traditional books (See the Presses de l'Université de Lyon site).

Theoretically, e-journals have many advantages for human and social sciences (the case of natural sciences is slightly different and would require a separate discussion). Low costs of production and especially of distribution, allowing academics to spend their meager and ever diminishing funds on other activities, easy indexation and access (provided a few recommendations about the structure of documents are implemented, which is still far from being the case) and a greatly improved « economy of writing " by the link system. There remain, however, numerous problems, in particular the maintenance of records, but they can all be solved through (the evolution of) technical devices or processes that will not utterly affect the content or-more importantly-the very process of production. This is why my intention is to point at other more complex and serious issues, those of the very function of journals and their place in the social sciences.

The vast majority of the existing publications are "mere " academic journals in electronic form/stored in electronic form, both in their structure, appearance, lay out (does such a word have any sense on the web ?), but even more seriously in the way content is produced. Our relationship to " the article " and to editing has remained the same, so has our relation to reading. Cognitive reasons are certainly part of the explanation, legal ones as well: the web is based on the principle of generalized quoting and recent court decisions as well as the standard laws of copyright tend to systematically undermine its epistemological logic. Political reasons are at work as well. Just as the generalized availability of computers has transferred the burden of technical and secretarial work in academia to scholars, thus lowering the material quality of academic publishing (in France at least), electronic publishing without serious financial backing will result in the same impoverishment by under-using the possibilities of the web (as opposed to commercial sites for instance) and results will be disappointing as they already are.

Eventually, if we do not boldly tackle (experimentally and theoretically) the question of what it is to write for the social sciences, we will merely produce more of the bad (and maybe more of the worst as well) ; all publishing will become vanity publishing (as is already the case almost everywhere); and the ancient hierarchies will create themselves again, especially in the near future when the so far surprisingly timorous commercial publishers will have understood their interest in the field (they are already controlling the market in the natural sciences).

There is for us a wonderful opportunity to control protection and keep it in our own hands, not to prevent debate and access but on the contrary to ensure that access and debate remain the backbones of our activity and social function. I do not know what the form(s) will be-or I'd be famous by now-but I know that e-journals will have to stop being objects (albeit electronic ones) to become «spaces» or «segments » in a continuum.

Conventional journals have increasingly become substitutes for books : as journals do not play the role they should and as too many books are printed which should never have seen the light of day, those that are needed may not always come to fruition-my 
comment here is not qualitative but epistemological. E-journals are part of the process which transforms ideas into scientific items (which in turn return to the idea stage, etc.), moving from fragments and opinions to statements. In French we have two words which translate into the same word in English, édition and publication, both meaning "publishing». However, they are not synonymous: publication is to make public (taking a scientific commitment and risk towards the community), often a temporary or topical act; édition is the result-or should be-of a maturation and sifting which « stabilizes » a network of ideas into a form having some sort of (limited) permanency.

Central to all scholarly publishing is the question of «validation ». Validation is not merely an assessment of abstract qualities but also of relevance, i.e. of choices which organize and structure a domain. But in the social sciences, a great part of the process is highly relative, which does not imply that anything goes. On the contrary, for such a fundamental act to take place in the best conditions, strong links between publications and real scholarly "projects " are indispensable. The publication (i.e. the publicizing) of research in social sciences until recently had been controlled and governed by those who had the power to allocate rare resources; today resources are virtually unlimited, thus displacing the inevitable process of « validation » from the controller of resources to the consumer. And electronic media, far from leading to mediocrity, allow a new test of validity, that of usage.

Indeed, publishing on the web means immediately exposing oneself (at least potentially) to the global community and thus taking a much greater risk. This point is also the strongest one to offer those who fear plagiarism: when something is electronically published, it is de facto protected by exposure and indexation. Publishing in an obscure conventional journal, on the contrary, can facilitate plagiarism. The same applies to theses or dissertations whose presence on the web automatically " copyrights » them, in a way no paper thesis or dissertation can ever be.

51 If the author needs protection, however, in this new environment where abundance has suddenly replaced scarcity, it is against himself. Editing and reviewing (by peers and technicians) must be as systematic as before but with different objectives as the article must be seen as merely a step in a dynamic process. For instance, it may be quite possible to publish simultaneously the paper and its reviews. On the whole, publishing on the web will increase the quality of publication, displace the real scholarly talent from the acquisition of information to its conceptualization (and originality); historiography will become the first necessary step to all research as opposed to simple bibliography, and the power that some derive from the management of secrecy and access to sources will slowly disappear.

52 Conversely, the concept of a journal issue, and of " putting the journal to sleep ", being potentially dead, journals run the risk of being mere repositories of contributions, simple data banks of unrelated papers with the publisher becoming a mere distributor (which is already the case of many publishers in France who, irrespective of electronic publishing, have now become mere printers and, in the best case, distributors). Such evolution would only mirror a general fragmentation of the social sciences and destroy what a journal is : a space where papers are positioned and not simply stored. This can be countered by fully playing the fluidity of the electronic form : dossiers for instance may grow over time, enriched by successive additions, extend also to other publication through critical links, as one speaks of a critical bibliography or a bibliographical essay, i.e. a discourse producing meaning over meaning. Thus, especially when financial 
stakes have receded, the bottom line is really the existence of true intellectual communities (and stakes) behind publication. This is why I think that what must be formed are clusters of publications (some electronic, some in paper form, some heavily edited, others fairly spontaneous) around learned societies-which should thus develop a scientific agenda-and around universities (for instance their presses) with the effect of resuscitating an ailing academic community. Other formulas-service platforms such as http://www.revues.org, which may serve a temporary purpose in formulating structural but certainly not intellectual principles-seem to me bound to disappear.

E-publishing really leads us to a debate on science, as a process where the impossible objectivity has been replaced by objectivized criticism, where the real production is not of statements (articles, books) but of debates. It can help us reinvent hierarchies and will allow the generalization of a model that was only reserved to the wealthy few and thus to democratize and improve research. It will also allow the development of new forms of presentation for research (Baker 1990) and of alternatives to English as a scientific language, the real participation in the construction of knowledge of our colleagues from the South and the actualization of a public service in the face of commercial interests. In short it may help the producers keep control over their production, not for themselves but so that it remains free, open, and alive.

Michel Bandry

54 (About the author: Professor, University of Montpellier 3, President of the English Studies Section of the Conseil National des Universités (French National Board of Evaluation))

To assess the status and importance of publications in the career of French academics, it may be necessary first to recall the different stages in the process of recruitment in the French universities. There are two levels of tenured positions : maitre de conférences (associate professor) and professeur des universités. To be appointed, a candidate must first receive a diploma from a University (a doctorate for the maîtres de conférences ; a doctorate and an habilitation à diriger des recherches-habilitation to supervise researchfor the professeurs). Then he/she must get a certification (qualification) from a national committee (the Conseil National des Universités, $\mathrm{CNU}$ ). Once he/she is certified, he/she can apply for one of the positions offered by different universities. His/her application is then examined by a local committee. The CNU in English is composed of 32 nationally elected members and 16 government appointed members, 24 professeurs, 24 maitres de conferrences who are specialists in the different fields that constitute the spectrum of English studies (linguistics, literature, civilisation, Great Britain, The United States,...).

At each stage, or each hurdle, the candidate is chosen, mostly, on the quality of his/her research and publications. For the maitres de conférences, it is mostly the doctoral dissertation which is the basis for choice. It does not have to be in book form. For the professeurs, the process is more complex. They are generally maitres de conférences and have had an experience in teaching in a university. The requirements for receiving an habilitation may differ from one university to another, but the candidates are expected to present a certain amount of printed material as proof of their research work after the defense of their doctoral dissertation, as well as a monograph in which they present the nature of their research, its problematics, define their projects and indicate in what way and what direction they could supervise doctoral students and participate in research groups. The evaluation process also takes into account the activity of the scholar in the research groups he belongs to, in his university or in national or 
international research centers, his participation in national and international seminars or conferences. It is, generally, the work of ten years or more that is thus evaluated.

The role of the CNU is to assess the value of this research work on a national basis and to make sure that the habilitation is not awarded on parochial criteria. The candidate submits his publications and monograph to the $C N U$, and this work is evaluated by two examiners who present an extensive written report to the whole assembly and give their opinion on the advisability of certifying or not the candidate. The decision of the $C N U$ is based on the opinion of the examiners who have read the whole body of material submitted. This evaluation is thus done mainly on the candidate's publications and the difficulty lies in assessing the value of the different publications submitted. A certain number of candidates have at least one book among their publications. This book is most often derived from their dissertation, in French or in English. When this book is published by a well-known French or foreign publisher, it is considered as a great asset. But, given the difficulty for French scholars to be published by serious publishers either in France or abroad, the material submitted by the candidates is mostly composed of articles or chapters of books.

The distinction is easily made between the articles published in " established » journals with an editorial board and an editorial policy that submits all articles to outside readers and other publications. An important part of each application file must be made of such articles published in French and international journals.

But the rest of the application file is most often composed of another type of publications : articles published in « local » journals (nearly each university has its own publication), seminar or conference proceedings, "on line» journals... whose readership is most often very limited. It has been the policy of the CNU these last ten years or so not to dismiss such publications as of little or no value on two conditions : the material submitted by the candidate must not be limited to this kind of publication and there must be evidence of a screening process in the decision to publish a contribution. This policy is founded on one consideration at least : the candidates must show that they are active in team research, that they animate and work within research groups most often in their own universities and the result of this research work appears through those «local» publications. Not to take such work into consideration would eventually deny any value to the work done locally and would discourage any attempt at doing serious research work in the universities. It would also discourage researchers from working in their universities.

60 It is the task of the $C N U$ to validate in a way those local and individual endeavors by giving an informed outside assessment on such publications. This validation is done through several levels of evaluation:

61 1- At least one of he $\mathrm{CNU}$ examiners is a specialist in the field (e.g., American literature, linguistics...);

62 2- The $C N U$ can and does submit publications to the appreciation of competent outside readers if need be ;

63 3- More generally, the $\mathrm{CNU}$, as a whole, has a clear picture of the value of the work done by the different research groups in the universities and of their reputation: individual contributions to the group research projects are thus assessed according to this reputation and judged in view of the original character of the work done, specially when they reflect one stage in a research in progress. 

especially the national associations. Their position places them in an ambivalent relation to journals, sometimes acting as allies and also as brakes on innovation. Journals and learned societies can in fact be caught either in shared strategies or in oppositional strategies. Learned societies have intellectual missions that are mitigated with others, less exalted, like defense of the profession, representation at official events, connection with the United States, interface with authorities, etc. They also have contacts with decision-makers at ministry level and with evaluators of the discipline and as such their activism may help promote the field of American studies, which makes them a dynamic ally. But they may be tempted to utilize the journal they sponsor as an official tool for control of the field as well, especially as they are interested in the cost-effectiveness of the publication and its certification power rather than its argumentation capacity. They can influence academic life, especially in their capacity to mobilize the research community, often around a ritual annual event, the Congress. They have an impact on the themes chosen and give currency and visibility to some trends over others, which can lead to oppositions, disaffections and to dissensions from the editorial committee, which may feel constrained by its lack of autonomy. Mostly, as institutions, they have not adjusted yet to the demands and the opportunities of on-line publishing, which doesn't need to be thematic to be federative. So they are a powerful actor in the field, that needs to be involved in new alliances to reform scholarly publishing, together with librarians, specialized bookstores and publishers.

We also need to develop our thinking around the very process of publishing and the role of journals in that process. This is particularly topical when dealing with a multidisciplinary field like ours, which invites our scholars to combine history, literature, sociology, cultural studies, visual semiotics, etc. This is particularly topical also with an international comparative domain like ours, where perspectives coming from all points of Europe can enrich our exchanges with American scholars in the United States.

Reconsidering the role of our productions, especially the status of the article, requires us to pay close attention to the open archives movement and to the e-print databases. They are important in helping us interact among ourselves as researchers, aside from certification; they also are a harbinger of the new, more direct, relations developing 
between creators of ideas and users of these ideas. Beyond copyright issues and intellectual property feuds, open archive databases for American studies could be interesting repositories of gray matter and works in progress. They could make our research more visible and accessible to a larger public, including the media. They should not be seen as substitutes to journals but as subsidiaries, with links between these different stages of research development. For more credibility and for the establishment of trust, some other agencies could be involved in the validation process, like the Centre national de la recherche scientifique (CNRS) in France.

These points need to be considered in common and the task started in Graz and Bordeaux, the regular convening of editors of journals within EAAS, should continue (see list appended below). Invitations should be extended to editors in related or neighboring fields. Reaching out to journals outside associations is essential to the current debate and to the finding of new alternatives and procedures. We also need to discuss with our web masters and coordinators, Jaap Verheul and Dick Ellis, how to develop and co-ordinate such a group. A mailbase, somehow connected with EAAS, seems like the first step to establish liaison with each other, though we are all overworked and backlogged... Another step is the setting up of a central internet website or portal, a sort of 'Omnibus Contents' as Dick Ellis puts it, on which we can display the contents pages of our publications, for mutual information and for EAAS members at large. It implies updating this portal as new issues of each of our journals appears. One of the topics for discussion on this portal should be the viability of the project of taking turns in producing special issues rather than creating a European journal on American studies; another topic of interest remains the open archiving option. These topics are not mutually exclusive.

Many questions remain up in the air, that might be worth a conference specifically dedicated to the future of publishing in our field : translation, referencing systems and standards, bibliometrics, the status of proceedings and preprints, trust and reciprocity, preservation of public domain, etc. To me, one fundamentally intriguing question remains, that of the black box, «Who is the end-user? » Is it a captive audience? Is it a monitoring body? Is it community of self-styled scholars? Is it large or confidential ? If we are moving toward a world of direct exchange between producer of ideas and user of these ideas, how do we start envisioning that reader? If we are moving towards on-line exchanges, how do we validate that interaction?

As these questions are not going to be answered in the near future, we should be grateful for journals...because they have given us the culture of installments. So, as we say in France, «à suivre »!

For Further Reading and Exchanging

73 «E-print ", available at http://www.eprints.org; see also http://www.eprints.org/self-faq/\#What-is-Eprint; http://www.eprints.org/self-faq/\#self-archiving-vs-publication. "Open Archives Initiative », available at http://www.openarchives.org BABOU, Igor et LE MAREC, Joelle. «Nova Atlantis - Manifeste pour une utopie baconienne en sciences humaines et sociales », Alliage 47 (2001). BAUDRILLARD, Jean. «Vers une société de l'immatériel », Les Clés du XXIe siècle. Paris : UNESCO/Éd. du Seuil, 2000. 
BORGMAN, Christine L. From Gutenberg to the Global Information Infrastructure, Access to Information in the Networked World. Boston : MIT Press, 2000.

BROWN, John Seely and DUGUID, Paul. The Social Life of Information. Boston : Harvard Business School P, 2000.

BUYDENS, M. La protection de la quasi-création. Bruxelles : Bruylant, 1993.

CATTELIN, Sylvie. «Internet ou la renaissance du mythe du savoir partagé », Les Cahiers de Médiologie 5 (1998).

CROW, Raym. « The Case for Institutional Repositories : A SPARC Position Paper », 2000. available at http://www.arl.org/sparc/IR/ir.html.

DARNTON, Robert. "The New Age of the Book », New York Review of Books, March 18, 1999, available on line at http://www.nybooks.com/articles/546.

DE LA VEGA, J-F. La communication scientifique à l'épreuve de l'Internet. L'émergence d'un nouveau modèle. Lyon : Presses de l'ENSSIB, 2000.

DERRIDA, Jacques. Papier machine. Paris : Galilée, 2001.

DUSOLLIER, S. «Le droit d'auteur et son empreinte digitale », Ubiquité 2 (Mai 1999) : 31-47.

ENSSIB. « Les défis de la publication sur le web », colloque organisé par l'ENSSIB dans le cadre des Quinzièmes entretiens du Centre Jacques-Cartier, 9-11 décembre, 2002 Lyon. Available at http://www.isdn.enssib.fr/cartier/colloque.htm

FRAU-MEIGS, Divina. Médiamorphoses américaines. Paris : Economica, 2001.

GRIFFITHS, José-Marie. « Why the Web is Not a Library », FID Review 11 (1999).

GUILLAUME, Marc. L'empire des réseaux. Paris : Descartes \& Cie, 1999.

HAMELINK, Cees J. Broadening the Acces to Information: Some Observations for a Future-Oriented Policy Brief. Paris : UNESCO, 2001.

HARNARD, S. «Post-Gutenberg Galaxy: The Fourth Revolution in the Means of Production of Knowledge », Public Access Computer Systems Review 21 (1991) : 39-53.

HUGENHOLTZ, P.B. "Copyright, contract and technology-What will remain of the public domain?", Le Droit d'auteur : un contrôle de l'accès aux œuvres ?, Cahier du CRID 18 (2000).

LAMOULINE, C. et POULLET, Y. Des autoroutes de l'information à la démocratie électronique, Rapport au Conseil de l'Europe, Oct. 1995, Bruxelles : Bruylant, Nemesis, 1996.

LE LOARER, Pierre. "L'édition électronique, rôle des médiateurs et nouveaux rapports au savoir », 70è congrès de l'Actab, session C-420, Québec, 2002. Available at http:// www.is.mcgill.ca/acfas70/C2669.htm

LESSIG, L. « The zones of cyberspace », Stanford Law Review (1996).

MACKIE-MASON, Jeffrey K, RIVEROS, Juan F. Economics and Electronic Access to Scholarly Information. Harvard Information Infrastructure Project, 1997, available at http:// www-personal.umich.edu/ jmm/papers/peak-harvard97/

MCSHERRY, C. Who Owns Academic Work? Battling For Control of Intellectual Property. Cambridge : Harvard UP, 2001.

NATIONAL HUMANITIES ALLIANCE. Basic Principles for Managing Intellectual Property in the Digital Environment, 1997. Document prepared for the Committee on Libraries 
and Intellectual Property of the National Humanities Alliance (NHA), available at http://www.ninch.org/issues/copyright/ principles/nha_complete.html,

NOYER, Jean-Max. «L'économie du savoir» Solaris 1 (1994) available at http:// web.ccr.jussieu.fr/urfist/cisa98.htm

PERRIAULT, Jacques. L'accès au savoir en ligne. Paris : Odile Jacob, 2002.

PROULX, Serge et LATZKO-TOTH, Guillaume. «La virtualité comme catégorie pour penser le social : l'usage de la notion de communauté virtuelle». Sociologie et société (Presses de l'Université de Montréal) 322 (2000) : 99-122.

QUÉAU, Philippe. La Planète des esprits, Pour une politique du cyberespace. Paris: Odile Jacob, 2000.

RIFKIN, Jeremy. The Age of Access. The New Culture of Hypercapitalism Where All of Life is a Paid-For Experience? New York : Putnam, 2000.

ROSE, Mark. Authors and Owners. The Invention of Copyright. Cambridge: Harvard UP, 1993.

SOUCHIER, Emmanuel, JEANNERET, Yves et LE MAREC, Joelle (eds). Lire, écrire, récrire objets, signes et pratiques des médias informatisés. Paris : BPI/Centre Pompidou (collection Etudes et recherche), 2003.

SUMMER, T., BUCKINGHAM, Shum S. «Open Peer Review and Argumentation: Loosening the Paper Chains on Journals » Ariadne 5 (2001), available at http:// www.ariadne.ac.uk/issue5/jime/intro.html

VANDENDORPE, Christian et BACHAND, Denis (eds). Hypertextes - espaces virtuels de lecture et d'écriture. Paris : Editions Nota Bene, 2002.

WOODMANSEE, Martha and JASZI, Peter (eds). The Construction of Authorship. Textual Appropriation in Law and Literature. Durham, N. Carolina : Duke UP, 1994.

WORMELL, Irene. "Adding Values to the Retrieved Information", FID Review 1 4/5 (1999).

List of Journals Supported by National American Studies Associations (with EAAS Membership)

American Studies in Scandinavia (Denmark, Sweden, Norway, Finland). Nordic Ass. For American Studies. (Nordic Journal of English Studies)

American Studies in Romania (Romania). The Romanian Ass. for American Studies.

Amerikastudien/American Studies (Germany). Deutsche Gesellschaft fur Amerikastudien.

Arbeiten aus Anglistik und Amerikanistik (Austria).

Atlantis (Spain). AEDEAN, Asociaciòn de Estudios anglo-norteamericanos.

Belgian Essays on Language and Literature (Belgium). BAAHE, Belgian Ass. of Anglicists in Higher Education.

GRAMMA : Journal of Theory and Criticism (Greece). HELAAS.

Irish Journal for American Studies (Ireland). Irish Association for American Studies.

Journal of American Studies (UK). BAAS, British Association for American Studies.

Journal of American Studies of Turkey (Turkey). American Studies Association of Turkey.

Op. Cit. A Journal of Anglo-American Studies (Portugal). APEAA, Portuguese Association of Anglo-American Studies. 
Revue Française d'Etudes Américaines (France). AFEA, Association Française d'Etudes Américaines.

RSA Journal (Italy). AISNA, Italian Ass. for North American Studies.

TransatlanticA (France). AFEA, Association Française d'Etudes Américaines.

\section{BIBLIOGRAPHIE}

BAKER, Howard. Sociological Forum 5 (November 1990) : 497-502.

CHARTRON, Ghislaine. « Les archives ouvertes dans la communication scientifique », 2002, available at http://www.ccr.jussieu.fr/urfist/archives-ouvertes.html.

DIDIER, Béatrice and ROPARS Marie-Claire (eds). Revue et Recherche. Paris, Presses Universitaires de Vincennes, 1994.

GUÉDON, Jean-Claude. «Open Access, Copyright and Evaluation : Reforming scholarly publishing through the recasting of academic alliances » 2003, available at http://www.ifla.org/V/iflaj/ ij-2-2003.pdf ; « In Oldenburg's Long Shadow : Librarians, Research Scientists, Publishers and the Control of Scientific Publishing ", available at http://www.arl.org/arl/proceedings/138/ guedon.html.

KEMPF, Jean. Rapport sur les études nord-américaines en France. Paris, Ministère de la recherche, 2002. Available at http://etudes.americaines.free.fr/rapport.html

QUÉAU, Philippe. « Global Governance and Knowledge Societies » Society for International Development (SID)'s Development Journal 5 (Dec. 2002).

QUINTON, Philippe. « Publier, éditer, exister... ». Place et enjeux des revues pour la recherche en infocom, actes du colloque de la SFSIC. Nice : LAMIC, 2002.

\section{RÉSUMÉS}

Ce débat a eu lieu dans le cadre du congrès annuel de l'AFEA à Rouen, le 30 mai 2003. Il a été publié dans le numéro européen de la Revue française d'études américaines (RFEA 98, décembre 2003, 116-137). Il est reproduit ici avec l'aimable autorisation des Editions Belin et l'accord de la rédaction de la RFEA.

\section{AUTEURS}

\section{MICHEL BANDRY}

Divina Frau-Meigs is co-editor of the Revue Française d'Etudes Américaines ; Catherine Bernard is editor of Les Cahiers Charles $V$, the journal of the Faculty of English and American Studies, University Paris 7, and joint-editor of The European Journal of English Studies, the official journal of the European Society for the Study of English ; Noëlle Batt 
is editor of TLE « recherche en revue » at University Paris 8 ; Jean Kempf is editor of Transatlantica ; Georges-Claude Guilbert is editor in charge of book reviews for Cercles at the University of Rouen ; Professor Michel Bandry is the former President of the English Studies Section of the Conseil National des Universités (national evaluation board for higher education) 